\title{
Habitat and Dietary Relationships of the Pygmy Rabbit
}

\author{
JEFFREY S. GREEN AND JERRAN T. FLINDERS
}

\begin{abstract}
Vegetal habitat characteristics and annual dietary selection were examined for the pygmy rabbit in southeastern Idaho. Areas selected for habitation by pygmy rabbits had a significantly greater woody cover and height than other areas. Total grass-forb biomass was similar in rabbit and nonräbbit sites. Grass biomass was least and forb biomass greatest where pygmy rabbits were most abundant. Sagebrush was eaten throughout the year, although in lesser amounts in summer $(51 \%)$ than in winter $(99 \%)$. Grasses and forbs were eaten through the summer ( 39 and $10 \%$, respectively) and decreased in the diet through fall to winter. Sagebrush is critical to the pygmy rabbit for both food and cover, although in this study, cover and height of woody vegetation appeared to be the critical features of the habitat selected for. This fact should be considered before brush removal treatments are applied within pygmy rabbit range.
\end{abstract}

Wildlife habitat research has been termed the "cornerstone in management" (Reynolds 1974) but is often poorly accomplished or entirely neglected. Manipulation of habitat is common, but should be undertaken with an understanding of resident wildlife species' requirements for food and space. Throughout the western United States, there is an historical and present day practice of removing sagebrush (Artemisia spp.) by spraying, mechanical treatment, and burning to increase forage production. Only

Green was at the time of the study, research associate, Botany and Range Science Department, Brigham Young University, Provo, Utah 84602. Current address is: U.S. Sheep Experiment Station, Dubois, Idaho 83423. Flinders is associate professor, director Wildlife and Range Resources Graduate Program, 407 WIDB, Brigham Young University, Provo, Utah $\mathbf{8 4 6 0 2 .}$

The efforts of Jeff Johansen and Forrest Luke, Laboratory Assistants, Brigham

Young University, for reading and preparing dietary slides is appreciated.

The work was supported by USDA Western Kegion Federal Cooperative Agreement No. 12-14-5001-264.

Manuscript received December 22, 1978. recently has the impact of this activity on wildlife been considered and then only for a few species (Powell 1969; Braun et al. 1977; Renwald 1977). Additional information is required before habitat can be altered for range improvement with a knowledge of possible impacts on wildlife populations.

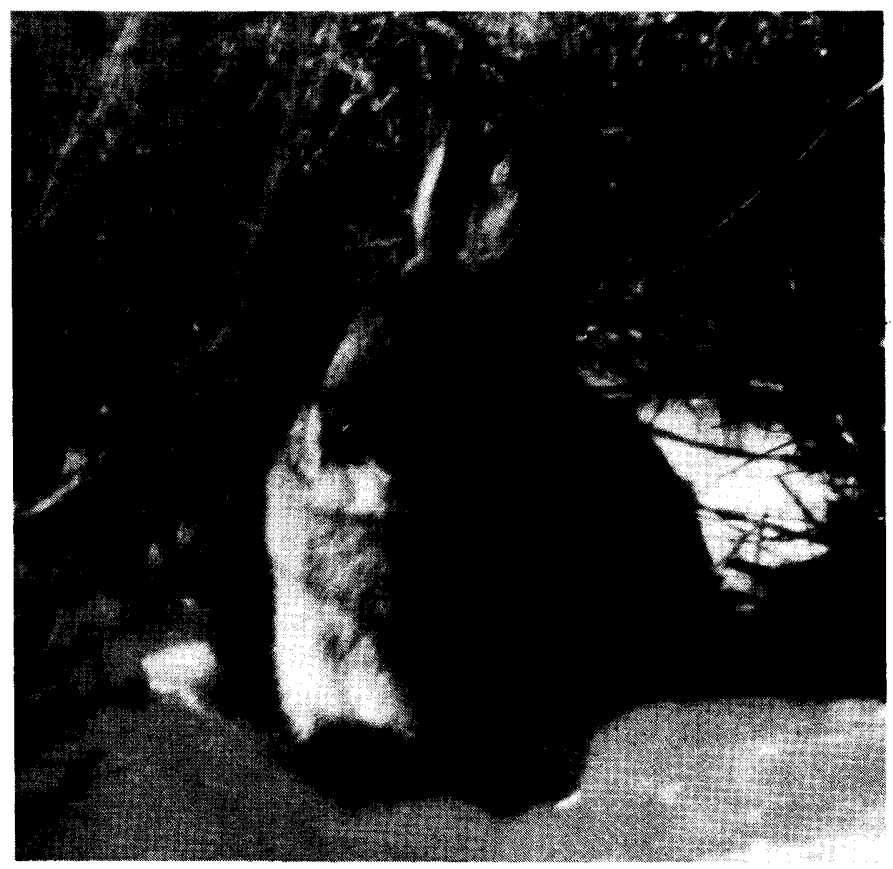

Fig. 1. Adult pygmy rabbit in winter pelage from Clark Co., Idaho (photo by J.S. Green). 
An examination of annual dietary habits is critical in a study of an animal's relationship to habitat. Food eaten depends on availability and preference. It is, therefore, imperative that an analysis be made of what is eaten and what is available. This necessitates direct observation, stomach or fecal analyses as well as vegetational examination of the habitat.

Leporids and particularly hares (Lepus), are important in the rangeland ecosystem and have been studied with respect to dietary habits and habitat (Hansen and Flinders 1972). Dietary data have also been compiled for cottontails (Sylvilagus) (Bailey 1969) and other members of this genus (Orr 1940).

The pygmy rabbit (Brachylagus idahoensis) (Green and Flinders 1980) (Fig. 1) is associated with the sagebrush complex of the Great Basin (Grinnell et al. 1930) and has escaped comprehensive investigation perhaps due to its inconspicuous nature (Severaid 1950). Janson (1946) noted some foods eaten by the pygmy rabbit and recently Wilde (1978) presented further dietary detail. However, information relating pygmy rabbit diet to vegetational availability has not been reported. This paper presents the results of a 2-year study of the pygmy rabbit relative to habitat characteristics and dietary selection. Included are information concerning deposition of fecal pellets and implications from grazing livestock.

\section{Study Area and Methods}

This study was conducted in 1977 and 1978 on the U.S. Sheep Experiment Station near Dubois, Idaho. The vegetation is characteristic of the sagebrush-grass complex of the Upper Snake River Plains and is detailed by Blaisdell (1958). Topography and soils are largely a result of volcanic activity. Precipitation averages $25 \mathrm{~cm}$ per year. This area is near the northeastern distributional boundary for the pygmy rabbit (Hall and Kelson 1959) and is also inhabited predominantly by the following small mammals listed in order of decreasing relative abundance: deer mouse (Peromyscus maniculatus), least chipmunk (Eutamias minimus), pocket mouse (Perognathus parvus), meadow vole (Microtus montanus), yellowbellied marmot (Marmota flaviventris) and the Uinta ground squirrel (Spermophilus armatus).

Seven sites were chosen to represent preferred pygmy rabbit habitat based on sightings of the study animals and evidence of abundant rabbit activity (pellets, runways, dusting areas and burrows). In each of the seven areas, 21 sampling points were established at 3-m intervals along . 2 intersecting perpendicular transects, each $30 \mathrm{~m}$ long. At each point, 2 permanent reference stakes were placed to allow consistent placement of a $1 / 4 \mathrm{~m}^{2}$ quadrat.

Rabbit fecal pellets were cleared initially from all quadrats in late April 1977 and were subsequently collected from each site as follows: late June, August, and October 1977, and late April, June, August, and October 1978. Fresh pellets were collected in winter in the general area of each site. Rabbit pellets from each site were pooled, counted, and analyzed for each collection period by microscopic examination of epidermal characters of vegetation (Flinders and Hansen 1972). [Dietary analysis of feces may underestimate some forbs in diets due to greater fragmentation of epidermal tissues that have decreased lignification (Hansson 1970).] Relative percent density of each food item was determined for all samples examined (Sparks and Malechek 1968).

Grasses and forbs were sampled in 6 of the 7 sites in late June 1977 and early July 1978 using a nested plot technique. Four random points were selected trom the 21 permanet points in each site per year. Five $1 / 4 \mathrm{~m}^{2}$ sampling plots were established at each point for a total of 20 plots per site. All grasses and forbs were clipped and weighed by species and oven dried to determine dry biomass.

Shrubs were sampled in late summer 1977 by measuring each plant by species in five $10-\mathrm{m}^{2}$ circular plots in each of the 6 sites as follows: (1) longest diameter of canopy; (2) longest diameter of the canopy measured at right angles to the dimension in (1); and (3) maximum height. Percent canopy cover for each species and total shrub cover were determined using the product of measurements (1) and (2). Dry biomass was estimated for each species by double sampling and linear regression (Uresk et al. 1977). Twenty plants of each species were chosen subjectively to represent various sizes ranging from small to large. After the aforementioned measurements were made, these plants were cut at ground level, dried at room temperature for 6 to 8 months, and weighed. Regression equations were calculated with volume (length $X$ width $X$ height) and dry biomass, and were used to estimate dry biomass of all other shrubs measured.

Comparable vegetative data were collected from 30 other sites on the Sheep Station in summer 1977. Some sites were selected randomly as small rodent areas while others were chosen as representative habitat for yellow-bellied marmots and Unita ground squirrels. One site within a livestock grazing exclosure was also examined. With respect to habitats for pygmy rabbits, the 30 sites were considered random since they represented a cross section of "other" habitats available but not selected for occupancy by pygmy rabbits. Woody and grass-forb vegetation were measured in the 30 sites by selecting random quadrats in a manner similar to the rabbit areas. In the grazing exclosure 20 grass-forb plots and five shrub plots were measured, while five grass-forb plots and two shrub plots were measured in all other sites.

Table 1. Regression equations and $r$ values to determine estimates of dry shrub biomass. $(\hat{\mathbf{y}}=a+b x$ for all shrubs except $P$ urshia tridentata, which is $\left.\hat{y}=a x^{b}\right)$

Species Regression equation

Correlation coefficient $(r)$
Amelanchier alnifolia

Artemisia tridentata

Artemisia tripartita

Chrysothamnus nauseosus

Leptodactylon pungens

Purshia tridentata

Rosa sp.

Symphoricarpos oreophilus

Tetradymia canescens

Xanthocephalum sarothrae
Chrysothamnus viscidiflorus $\hat{y}=6.44+.001311 x$

$\hat{y}=7.589+.001 x$ (for plants with volume $\left.\leq 61,000 \mathrm{~cm}^{3}\right)$

$\hat{y}=136.837+.00128 x$ (for plants with volume $61,000 \mathrm{~cm}^{3}$ )

$\hat{y}=.53+.00215 x\left(\right.$ for plants with volume $\left.\leq 65,000 \mathrm{~cm}^{3}\right)$

$\hat{y}=-38.948+.00238 x$ (for plants with volume $>65,000 \mathrm{~cm}^{3}$ )

$\hat{y}=-4.79+.00114 x$

$\hat{y}=.52+.00234 x$

$\hat{y}=7.18+.00119 x$

$\hat{y}=.0193 x^{.802}$

$\hat{y}=.42+.00062 x$

$\hat{y}=16.9+.00061 x$

$\hat{y}=12.21+.00186 x$

$\hat{y}=69+.000637 x$ a $y=$ estimated dry weight, $x=$ shrub volume (maximum length $x$ maximum perpendicular width $\times$ maximum height) 


\section{Results and Discussion}

Woody Vegetation

Regression equations to determine dry biomass were developed for the major shrub species found in the rabbitoccupied sites and other areas (Table 1). The highly significant $(P \leq 0.01)$ correlation coefficients indicate predictions of dry biomass are acceptable. Mean percent cover and dry biomass estimates for the shrubs are listed in Table 2 . Analysis of variance for cover measurements on individual plots within each site showed no significant difference in total cover between any sites except the rabbit areas. (Nonsignificance in all tests is $P>0.05$.) Pygmy rabbit habitat had a significantly greater $(P \leq 0.01)$ cover and corresponding biomass of woody vegetation than any other site examined. There was, however, no significant difference in mean percent cover between individual pygmy sites.

There was no significant difference in mean percent cover for bitterbrush (Purshia tridentata) between any pygmy sites except site 3 , where this shrub was absent. Combining both threetip and big sagebrush (A. tripartia and tridentata), there were no significant differences for cover between pygmy sites except site $1(P \leq 0.01)$.

Mean height of the shrub canopy for all pygmy rabbit sites was $56 \mathrm{~cm}\left(S_{\mathrm{x}}=2.8\right)$ with no significant differences between sites. The mean height of the canopy for all other sites was $25 \mathrm{~cm}\left(S_{\mathrm{x}}=1.4\right)$. There were no significant differences between sites. A highly significant difference ( $P$ $\leq 0.01$ ) was found between the shrub canopy height of the pygmy rabbit sites compared to all other sites.

The greater shrub cover and height in pygmy rabbit habitat was expected from a review of the literature. Orr (1940:194) stated that tall sagebrush in "dense clumps" was apparently essential to the rabbit, and others have made similar observations (Grinnell et al. 1930; Borell and Ellis 1934; Severaid 1950).

\section{Grass-Forb Vegetation}

Dry biomass data for grasses and forbs from all areas sampled are detailed in Table 3. Analysis of variance and the least significant difference test showed no significant difference in total mean biomass for any sites. Considering grass biomass alone, the exclosure and pygmy sites were significantly different $(P>0.01)$ from the ground squirrel sites. Our other research shows ground squirrels feed primarily on grasses and thus inhabit moist sites where grass vegetation is more abundant. There was no significant difference in mean forb biomass between sites.

Grass-forb vegetation for the pygmy rabbit sites is listed in Table 4. There are no significant differences between sites with respect to total biomass. However, sites 5 and 6 had a significantly lower $(P \leq 0.05)$ grass component than the other sites and a significantly higher $(P \leq 0.05)$ forb component than sites 1,2 , and 3 . Site 7 had a significantly lower $(P \leq 0.05)$ forb biomass than site 5 . Possible reasons for this disparity will be discussed later.

\section{Diet}

Foods eaten by pygmy rabbits on an annual basis are detailed in Table 5. Food items were taken in similar amounts from shrubs, grasses, and forbs from spring (May) through fall (October) (hereafter termed summer period). During this period, a mean relative density of $51 \%$ shrubs, $39 \%$ grasses, and $10 \%$ forbs appeared in rabbit pellets in all sites. No significant differences between sites were observed. Significant differences $(P \leq 0.01)$ were found, however, between amounts of foods consumed in the summer, winter (December through February), and early spring (March through April) periods. Sagebrush was eaten almost exclusively during winter. With the onset of spring and coincident vegetation "green-up," grasses and forbs increased in frequency of occurrence in fecal pellets. On an annual basis, a mean of $67 \%$ shrubs, $26 \%$ grasses, and $6 \%$ forbs was consumed (Table 5).

Wilde (1978) reported that on the Idaho National Engineering Site in southeastern Idaho, the pygmy rabbit had two main dietary periods: winter, extending from

Table 2. Mean percent cover and total dry biomass for the major woody species found in the rabbit sites and other areas.

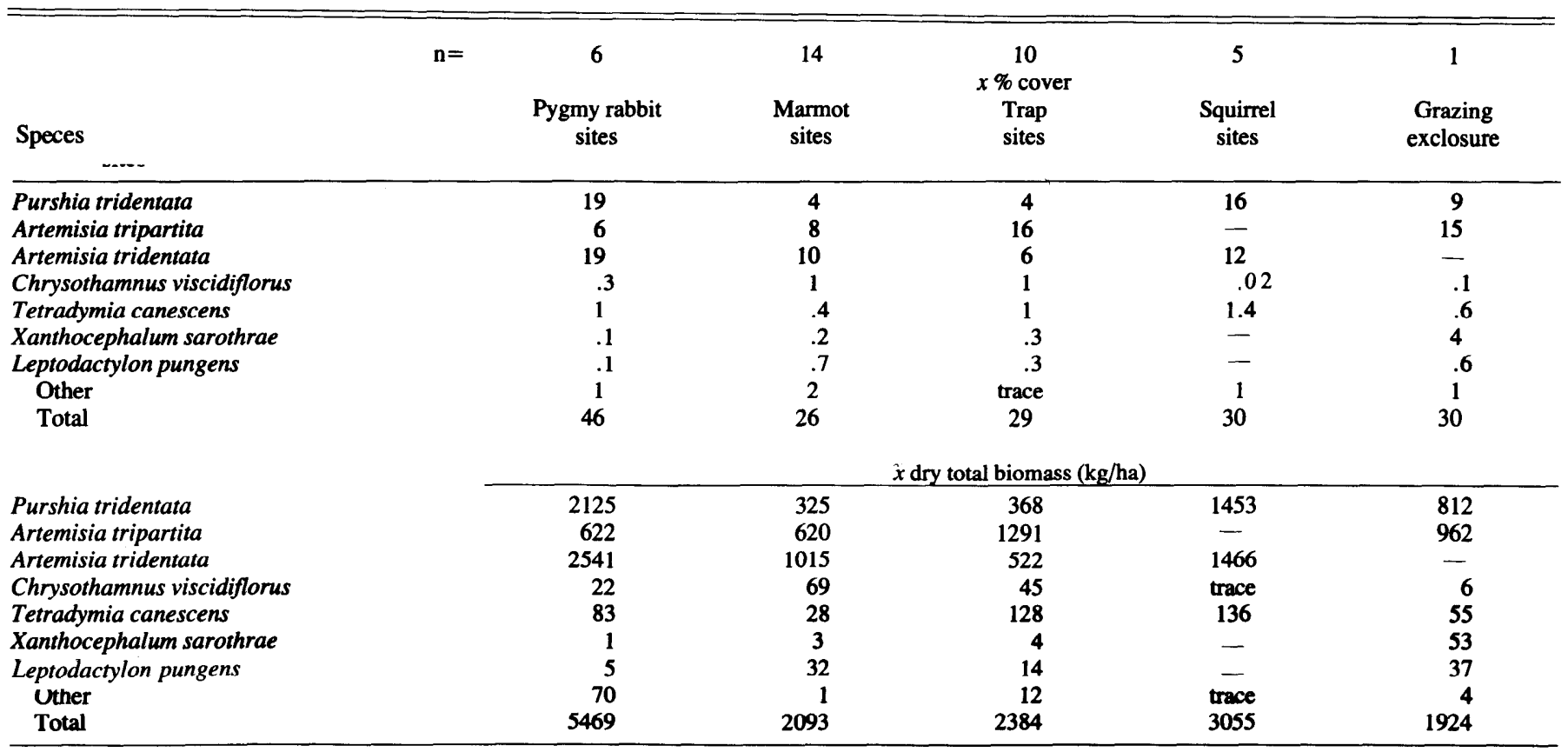


Table 3. Mean dry biomass ( $\mathrm{x} \mathrm{kg} / \mathrm{ha}$ ) for major grass and forb species in the pygmy sites and other areas.

\begin{tabular}{|c|c|c|c|c|c|}
\hline Species & $\begin{array}{l}\text { Rabbit } \\
\text { sites }\end{array}$ & $\begin{array}{l}\text { Marmot } \\
\text { sites }\end{array}$ & $\begin{array}{l}\text { Trap } \\
\text { sites }\end{array}$ & $\begin{array}{l}\text { Squirrel } \\
\text { sites }\end{array}$ & $\begin{array}{l}\text { Grazing } \\
\text { exclosure }\end{array}$ \\
\hline \multicolumn{6}{|l|}{ Grasses } \\
\hline Agropyron dasystachyum & 103 & 120 & 72 & 344 & 12 \\
\hline Agropyron spicatum & 40 & 44 & 129 & & 156 \\
\hline Calamagrostis montanensis & 6 & 32 & 72 & 236 & \\
\hline Carex spp. & 12 & 7 & 6 & 14 & trace \\
\hline Koeleria cristata & 3 & 6 & 24 & 5 & 36 \\
\hline Poa nevadensis & 67 & 23 & 98 & 78 & 36 \\
\hline Poa spp. & $<36$ & - & - & - & $<18$ \\
\hline Stipa comata & 34 & 68 & 15 & 48 & 28 \\
\hline \multicolumn{6}{|l|}{ Forbs } \\
\hline Achillea millefolium & 11 & 1 & 14 & 5 & - \\
\hline Antennaria rosea & 6 & 53 & 26 & 23 & 8 \\
\hline Astragalus spp. & 4 & 5 & 27 & 20 & 12 \\
\hline Balsamorhiza sagittata & 178 & 1 & 17 & - & 76 \\
\hline Eriogonum spp. & 18 & 21 & 8 & 8 & 102 \\
\hline Lupinus caudatus & 12 & - & 3 & - & 10 \\
\hline Phlox spp. & 14 & 4 & 10 & trace & 4 \\
\hline Total $x$ grass biomass & $316(51)^{\prime}$ & $522(77)$ & $474(73)$ & $742(85)$ & $286(46)$ \\
\hline Total $x$ forb biomass & 309 & 153 & 171 & 131 & 330 \\
\hline Total $x$ grass-forb biomass & 625 & 675 & 645 & 873 & 616 \\
\hline
\end{tabular}

*Number in parenthesis is a percent of total grass-forb biomass.

October to May, and a summer period, the remainder of the year. He further reported that sagebrush was the single most important food item throughout the year, never with a relative frequency $<36 \%$. Forbs were not found in scat with a frequency $>12 \%$ and grass consumption peaked to 30 to $40 \%$ in June through August.

Wheatgrass (Agropyron spp.) and Nevada bluegrass (Poa nevadensis) were consumed with greater frequency than other grasses. Wheatgrass occurred in pellets uniformly throughout the summer period while bluegrass occurred with greater frequency in early summer (Table 5). Wheatgrass and bluegrass consumption was greater in early summer 1978 than the same period in 1977 (56\% and 37\%, respectively) while availability of those grasses did not differ appreciably between years ( $2.5 \%$ and $3 \%$, respectively). The reason for this differential consumption is not known. Wilde (1978) reported a dietary transition from wheatgrass and bluegrass in early summer to wildrye (Elymus sp.) and needleandthread (Stipa sp.) in August and September. Although needleandthread occurred in the habitat with the same frequency as bluegrass in our study, it never appeared in significant amounts in the diet.

Mean preference indices (PI) for the major plant species eaten by pygmy rabbits in all sites were calculated using the formula: $\mathrm{PI}=$ (relative $\%$ of item in diet $) \div$ (relative $\%$ of item in habitat). The PI for sagebrush was 1 , indicating that it was eaten in the same proportion as it occurred in the habitat. Indices greater than 1 indicate that the item was eaten in a greater proportion than it occurred in the habitat. Therefore, the PI may show preferred food items (high values) and also the relative amount of energy expended by the rabbits to seek and consume the item. Bluegrass and wheatgrass had the highest PI's of all food items (14 and 37, respectively) and were the grasses found most frequently in fecal pellets from all sites. Consequently, a greater energy expenditure is required to seek and consume these two grass species than any other plants regularly eaten. Preference indices for other plants eaten were as follows: cheatgrass (Bromus tectorum), 5; sedge (Carex spp.), 5; needleand- thread, 1; common yarrow (Achillea millefolium), 8; rose pussytoes (Antennaria rosea), 4; astragalus (Astragalus spp.), 7; and lupine (Lupinus spp.), 3.

An index of similarity (SI) between pygmy rabbit diet and each habitat grouping was calculated for early summer 1977 using the formula: $\mathrm{SI}=(\Sigma$ minimum value $\div \Sigma$ maximum value) (100). The following values were obtained: for pygmy rabbit habit, $48 \%$; for the grazing exclosure, $47 \%$; for the marmot sites, $49 \%$; for the rodent trapping sites, 34\%; and for the Uinta ground squirrel sites, $49 \%$. An SI of $100 \%$ would indicate that food items were eaten in identical proportion to their occurrence in the habitat. The SI values for pygmy rabbit, marmot, and ground squirrel habitat are similar and indicate that each of these areas would be equally suited for pygmy rabbits with respect to availability of vegetation for food. The fact that pygmy rabbits are not found to any degree in marmot and ground squirrel habitat demonstrates that something other than diet may primarily influence habitat selection by pygmy rabbits in this study area.

Similarity indices for habitat and diet in six pygmy rabbit sites ranged from $13 \%$ to $64 \%$. Although this range is relatively wide, consumption of food items was similar in all sites and did not appear to be controlled by vegetative availability.

\section{Fecal Deposition}

Fecal deposition data were collected from 9 adult pygmy rabbits (4 males and 5 females) which were part of a laboratory colony. Pellets were collected daily for 9 consecutive days, counted, dried, and weighed. Mean defecation rate for the rabbits was $36.09\left(S_{\bar{x}}=2\right)$ pellets per hour for a 24 -hour mean total of 866 pellets. Nine pellet groups were counted showing a mean of $67.78\left(S_{x}=5.4\right)$ pellets per group. By dividing daily defecation rate by the mean pellets per group, a mean of 12.78 pellet groups per day was determined in the laboratory for the pygmy rabbit.

Fecal pellets were collected from all field sites at 2-month intervals except during winter. Therefore, the late April 
Table 4. Mean grass-forb vegetative biomass for pygmy rabbit sites in 1977 and $1978(\mathrm{~kg} / \mathrm{ha})$.

\begin{tabular}{lccc}
\hline \hline Site & Total biomass & $\begin{array}{c}\text { Grass biomass } \\
\text { (\% of total) }\end{array}$ & Forb biomass \\
\hline 1 & 609 & $494(81)$ & 115 \\
2 & 543 & $316(59)$ & 227 \\
3 & 573 & $388(68)$ & 185 \\
5 & 917 & $199(24)$ & 719 \\
6 & 734 & $111(16)$ & 623 \\
7 & 777 & $420(54)$ & 357 \\
\hline
\end{tabular}

1978 sampling represents a 5-month pre-collection period (November 1977 to April 1978) and is not used in calculation of the site means listed in Table 6 . The mean collection totals for sites 5 and 6 were significantly greater $(P \leq 0.01)$ than means for the other sites. There was no significant difference between the mean totals for each collection period.

The sampling scheme for vegetation effectively measured identical portions of pygmy rabbit habitat. Since the mean defecation rate for the pygmy rabbit appears to be relatively constant, the greater number of pellets found in sites 5 and 6 indicates more rabbits inhabiting those two areas. Correlation coefficients $(r)$ were calculated using linear regression between the mean bimonthly number of pellets per site and the following variables: shrub cover and height, sagebrush, forb, and grass biomass. Forb biomass was positively correlated $(r=0.92, P \leq 0.01)$, and grass biomass was negatively correlated $(r=-0.91, P \leq 0.01)$ with the number of fecal pellets deposited. No other associations showed significant correlations.

There are no published quantitative data available for pygmy rabbit habitat. Census methods for this species make subjective inference necessary when investigating population density. In this study, some habitat parameters and one means of objectively assessing relative numbers of pygmy rabbits in various sites have been quantified. Based on these parameters, there was a significant decrease in mean grass biomass and a significant increase in mean forb biomass where pygmy rabbit were most abundant.

Several factors may influence the grass-forb ratio in the pygmy sites. Season and intensity of livestock grazing influences vegetation. Fall grazing with light spring grazing is less injurious to grasses and forbs than summer grazing (Mueggler 1950). In this study, we assume the impact of livestock grazing has been similar in all pygmy rabbit sites; however, realistically, differences in grazing pressure may have occurred.

Soil characteristics within and between pygmy rabbit sites influence vegetative composition. Based on a soil survey completed on the Sheep Station in 1969 by the Soil Conservation Service, pygmy sites 1, 5, 6, and 7 are in the same soil complex and sites, 2, 3, and 4 are in related complex. There are likely soil phase differences within each site, however, that affect the vegetative component in a complex manner. Thus we cannot necessarily expect pygmy sites within a particular soil series to be comparable in all vegetative respects. Shrub height and canopy cover may be similar while the grass-forb ratio could be different.

Environmental conditions, particularly precipitation, may affect vegetation composition on an annual basis. Pygmy rabbit sites were ranked according to biomass of grasses, forbs, and total biomass for each of the 2 years of this study. Spearman's rank correlation coefficients (rho) were calculated for each ranking as follows: grass, .934; forbs, 1.0; and total biomass, .49. During the period of this study, therefore, there was little change in ranking of grass

Table 5. Vegetation eaten annually by pygmy rabbits in southeastern Idaho (figures are a mean \% relative density for the 7 rabbit sites).

\begin{tabular}{|c|c|c|c|c|c|c|}
\hline & May-June & July-Aug. & Sept.-Oct. & Dec. -Feb. & Mar.-Apr. & Annual mean ${ }^{1}$ \\
\hline \multicolumn{7}{|l|}{ Shrubs } \\
\hline Artemisia spp. & 47 & 43 & 57 & 99 & 80 & \\
\hline Purshia tridentata & - & 2 & 1 & - & 2 & \\
\hline Chrysothamnus nauseosus & - & - & - & - & 1 & \\
\hline Ribes spp. & - & 1 & - & - & - & \\
\hline Other & 1 & 1 & - & - & - & \\
\hline Total (7 species) & 48 & 47 & 58 & 99 & 83 & 67 \\
\hline Grasses & & & & - & & \\
\hline Agropyron spp. & 27 & 36 & 26 & 1 & 7 & \\
\hline Bromus tectorum & - & 1 & - & - & trace & \\
\hline Carex spp. & 1 & 1 & - & - & - & \\
\hline Koeleria cristata & - & - & 1 & - & trace & \\
\hline Oryzopsis hymenoides & trace & 1 & - & - & - & \\
\hline Poa nevadensis & 12 & 1 & 3 & - & 6 & \\
\hline Stipa comata & trace & & - & - & - & \\
\hline Other & 3 & 2 & 1 & - & 2 & \\
\hline Total (13 species) & 43 & $4 \overline{2}$ & 31 & 1 & 15 & 26 \\
\hline \multicolumn{7}{|l|}{ Forbs } \\
\hline Achillea millefolium & 3 & trace & trace & & - & \\
\hline Antennaria rosea & 3 & 3 & 4 & & - & \\
\hline Astragalus spp. & 1 & 2 & 3 & & trace & \\
\hline Eriogonum heracleoides & & - & 2 & & 2 & \\
\hline Lupinus spp. & trace & 1 & trace & & - & \\
\hline Penstemon spp. & 1 & trace & & & - & \\
\hline Other & 2 & 2 & 2 & & & \\
\hline Total (16 species) & 10 & 8 & 11 & & 2 & 6 \\
\hline
\end{tabular}

\footnotetext{
${ }^{1}$ Note. Due to trace amounts and plants identified as unknowns, the annual mean column does not total 100.
} 
Table 6. Data from collection of pygmy rabbit fecal pellets for 2-month intervals (except the late April 78 period).

\begin{tabular}{lcccccccc}
\hline & \multicolumn{10}{c}{ Total pellets from each of 7 sites } \\
\cline { 2 - 9 } Collection date & 1 & 2 & 3 & \multicolumn{1}{c}{4} & \multicolumn{1}{c}{5} & \multicolumn{1}{c}{6} & 7 & $\hat{\mathbf{x}}$ \\
\hline Late June 77 & 469 & 649 & 556 & 475 & 879 & 1368 & 343 & 677 \\
Late Aug. 77 & 575 & 664 & 583 & 468 & 959 & 656 & 493 & 628 \\
Late Oct. 77 & 405 & 443 & 472 & $57^{1}$ & 1521 & 973 & 465 & 713 \\
Late Apr. 78 & 457 & 800 & 778 & 497 & 1356 & 826 & 585 & 762 \\
Late June 78 & 375 & 333 & 174 & 95 & 810 & 1355 & 554 & 528 \\
Late Aug. 78 & 377 & 326 & 568 & 191 & 981 & 666 & 136 & 464 \\
Late Oct. 78 & 427 & 212 & 581 & 298 & 643 & 593 & 333 & 441 \\
$\quad x^{2}$ & 438 & 438 & 489 & $305^{3}$ & 966 & 935 & 387 & \\
\hline
\end{tabular}

' Partial snow cover precluded a $100 \%$ pellet collection.

2 Omitting late April 78 collection data because of the potential 5 month pre-collection period.

3 Omitting late Oct. 77 collection data.

and forb biomass between the six pygmy rabbit sites examined while total biomass ranking varied with years.

The data from this study may support the following hypothesis. Dietary analysis indicates that pygmy rabbits consume wheatgrass and bluegrass throughout the summer period while consuming forbs to a lesser degree. Therefore, rabbits may initially inhabit areas that contain abundant grass, provided that all other habitat requirements are met (i.e. adequate sagebrush cover and height). Following a period of time, total grass biomass may be reduced through selective removal by rabbits and forb biomass may increase due to negative selective pressure. Concurrently, a decrease in grass vigor would allow a competitive advantage to forbs. A similar process may have occurred in parts of the Wasatch Plateau, Utah, where forbs dominate in areas that have been grazed by cattle for many years (Ellison 1954). Cattle prefer grasses to forbs (Stoddart et al. 1975) and may have caused forbs to increase through selective pressure on grasses. Validity of the proposed grass depletion theory is related to the ability of the habitat to produce sufficient grass for summer food requirements of rabbits. From an evolutionary standpoint, it may not be advantageous for the rabbit to decrease the grass component to the point that a new habitat has to be selected.

Wilde (1978) observed that transition to grass consumption during the summer may insure minimal damage to sagebrush, which is the critical winter food for pygmy rabbits. He further observed that the pygmy rabbit does not respond to an abundant spring food supply in favorable years by producing extra litters similar to other rabbit species. Therefore, numbers of pygmy rabbits may fluctuate less than other leporids, indicating a close harmony with their climax-type vegetational community and a decreased reliance on variable grass production.

Consumption of grasses in spring through summer is also related to reproduction. Green vegetation is important for reproduction in small rodents (Van De Graaf and Balda 1973) and dietary restrictions influence breeding in rabbits (Kirkpatrick and Kibbe 1971). Wilde (1978) concluded that vegetation was also a key to reproductive readiness in the female pygmy rabbit.

There are implications with respect to the pygmy rabbit and livestock grazing. Comparisons between forage intake for rangeland grazers can be made using the formula reported by Dasmann (1971:33), where air-dry forage requirements are related to the seventy-three hundredth power of the live weight of the animal in question. For a 64- $\mathrm{kg}$ sheep, the formula shows a daily consumption of $2.08 \mathrm{~kg}$ of air-dry forage. This estimate compares to published values for sheep, which range from 1.35 to $2.25 \mathrm{~kg} /$ day depending on reproductive condition (Cullison 1975). Accordingly, the following daily forage consumptions are calculated: for a 46-kg deer, $1.63 \mathrm{~kg} /$ day [compare with 1.36 to $1.81 \mathrm{~kg} /$ day (Dasmann 1971)]; for a $2.5-\mathrm{kg}$ jackrabbit, 20 $\mathrm{kg}$ /day [compare with .09 to $.13 \mathrm{~kg} / \mathrm{day}$ (Flinders and Hansen 1972)]; and for a .45-kg pygmy rabbit, $.06 \mathrm{~kg} / \mathrm{day}$. It appears that the formula overestimates forage consumption as the size of the animal decreases but it has value for comparative purposes. The pygmy rabbit consumes about $1 / 4$ the amount of forage as a jackrabbit and about $1 / 35$ the amount of forage as a sheep. Sheep prefer forbs (Stoddart et al. 1975) and pygmy rabbits prefer grass to forbs in summer. Therefore, the pygmy rabbit may compete minimally with sheep for forage on rangeland where forbs are sufficiently abundant and may even enhance forb production by selective grazing of grasses. Pygmy rabbits may compete with cattle for grasses.

\section{Summary and Conclusions}

The pygmy rabbit is generally restricted to the sagebrushgrass complex of the Great Basin although Davis (1939) reported the animal also in areas where greasewood (Sarcobatus) was abundant. Six habitat sites occupied by pygmy rabbits were analyzed for vegetational characteristics and composition and compared to other random sites that were not inhabited by pygmy rabbits. Woody cover and shrub heights were significantly greater in the pygmy rabbit sites, while no significant differences were observed in total grass-forb biomass between sites.

Pygmy rabbits ate sagebrush throughout the year but in lesser amounts in summer $(51 \%)$ than in winter $(99 \%)$. Other shrubs were consumed infrequently. Grass and forb consumption was relatively constant throughout the summer (39 and 10\%, respectively) and decreased to a trace amount through fall to winter. Wheatgrass and bluegrass were highly preferred foods in the summer period while forbs were eaten only occasionally in all sites.

Data from deposition of fecal pellets indicated relative abundance of rabbits, and decreased grass with increased forb biomass in the 2 sites where rabbits were most abundant. This may be due to selective grazing pressure on grasses by the pygmy rabbits and could benefit sheep but be detrimental to cattle where pygmy rabbit habitat coincides with livestock grazing.

Research with a captive colony of pygmy rabbit indicates that they have preferences for certain species and subspecies of sagebrush and quickly succumb when essential food items are not available. Compared to a maximum similarity index of $100 \%$, which indicates items are eaten in proportion to their occurrence in the habitat, the SI of $48 \%$ between pygmy rabbit diet and their habitat indicates that dietary selection also takes place in the natural environment. However, comparable similarity indices were also obtained with pygmy rabbit diet and habitat for marmots and ground squirrels. These sites did not contain pygmy rabbits to any degree. Therefore, in this study area, cover appeared to be the critical habitat feature selected by the pygmy rabbit. Other subtle variations in the vegetative component of the habitat may help to explain why areas with "appropriate looking" woody vegetational physiognomy do not 
necessarily constitute suitable pygmy rabbit habitat. Due to specialized habitat features selected for by pygmy rabbits, prudent consideration should precede sagebrush eradication where these animals occur.

\section{Literature Cited}

Bailey, J.A. 1969. Exploratory study of nutrition of young cottontails. J. Wildl. Manage. 33:346-353.

Blaisdell, J.P. 1958. Seasonal development and yield of native plants on the Upper Snake River Plains and their relation to certain climatic factors. U.S. Dep. Agr. Tech. Bull. No. 1190.

Borell, A.E., and R. Ellis. 1934. Mammals of the Ruby Mountain Region of northeastern Nevada. J. Mammal. 15:12-44.

Braun, C.E., T. Britt, and R.O. Wallestad. 1977. Guidelines for maintenance of sage grouse habitats. Wildl. Soc. Bull. 5: 99-106.

Cullison, A.E. 1975. Feeds and Fecding. Reston Publishing Co., Inc., Reston, Virginia.

Dasmann, W. 1971. If deer are to survive. Stackpole. $128 \mathrm{p}$.

Davis, W.B. 1939. The Recent Mammals of Idaho. Caxton Printers, Ltd., Caldwell, Idaho. $400 \mathrm{p}$.

Ellison, L. 1954. Subalpine vegetation of the Wasatch Plateau, Utah. Ecol. Monog. 24:89-184.

Flinders, J.T., and R.M. Hansen. 1972. Diets and habitats of jackrabbits in northeastern Colorado. Range Sci. Dep. Sci. Ser. No. 12. Colorado State Univ., Fort Collins.

Green, J.S., and J.T. Flinders, 1980. Brachylagus idahoensis. Mammal. Species. In press.

Grinnell, J., J. Dixon, and J.M. Linsdale. 1930. Vertebrate natural history of a section of northern California through the Lassen Peak Region. Univ. California Pub. Zool. 35:1-594.

Hall, E.R., and K.R. Kelson. 1959. The Mammals of North America. Ronald Press Co., New York. 1083 p.

Hansen, R.M., and J.T. FLinders. 1969. Food habits of North American hares. Range Sci. Dep. Sci. Ser. No. 1. Colorado State Univ., Fort Collins. $17 \mathrm{p}$.

Hansson, L. 1970. Methods of morphological diet micro-analysis in rodents. Oikos 21:255-266.

Janson, R.G. 1946. A survey of the native rabbits of Utah with reference to their classification, distribution, life histories and ecology. MS Thesis. Utah State Univ., Logan.

Kirkpatrick, R.L., and D.P. Kibbe. 1971. Nutritive restriction and reproductive characteristics of captive cottontail rabbits. J. Wildl. Manage. 35:332-338.

Mueggler, W.F. 1950. Effects of spring and fall grazing by sheep on the vegetation of the upper Snake River Plains. J. Range Manage. 3:308-315.

Orr, R.T. 1940. The rabbits of California. Occas. Papers California Acad. Sci., 19:1-227.

Powell, J. 1969. Rodent numbers on different brush control treatments in south Texas. Texas J. Sci. 20:69-76.

Renwald, J.D. 1977. Effect of fire on lark sparrow nesting densities. J. Range Manage. 30:283-285.

Reynolds. H.G. 1974. Habitat research...cornerstone in management. New Mex. Wildl. 19:28-30.

Severaid, J.H. 1950. The pygmy rabbit (Sylvilagus idahoensis) in Mono County, California. J. Mammal: 31:1-4.

Sparks, D.R., and J.C. Malachek. 1968. Estimating percentage dry weight in diets using a microscopic technique. J. Range Manage. 21:264-265.

Stoddart, L.A., A.D. Smith, and T.W. Box. 1975. Range Management. Third Edition. McGraw-Hill Book Co., New York. 532 p.

Uresk, D.W., R.O. Gilbert, and W.H. Rickard. 1977. Sampling big sagebrush for phytomass. J. Range Manage. 30:311-314.

Van De Graaff, K.M., and R.P. Balda. 1973. Importance of green vegetation for reproduction in the kangaroo rat, Dipodomys merriami merriami. J. Mammal. 54:509-512.

Wilde, D.B. 1978. A population analysis of the pygmy rabbit (Sylvilagus idahoensis) on the INEL site. Unpub. PhD Diss. Idaho State Univ., Pocatello.

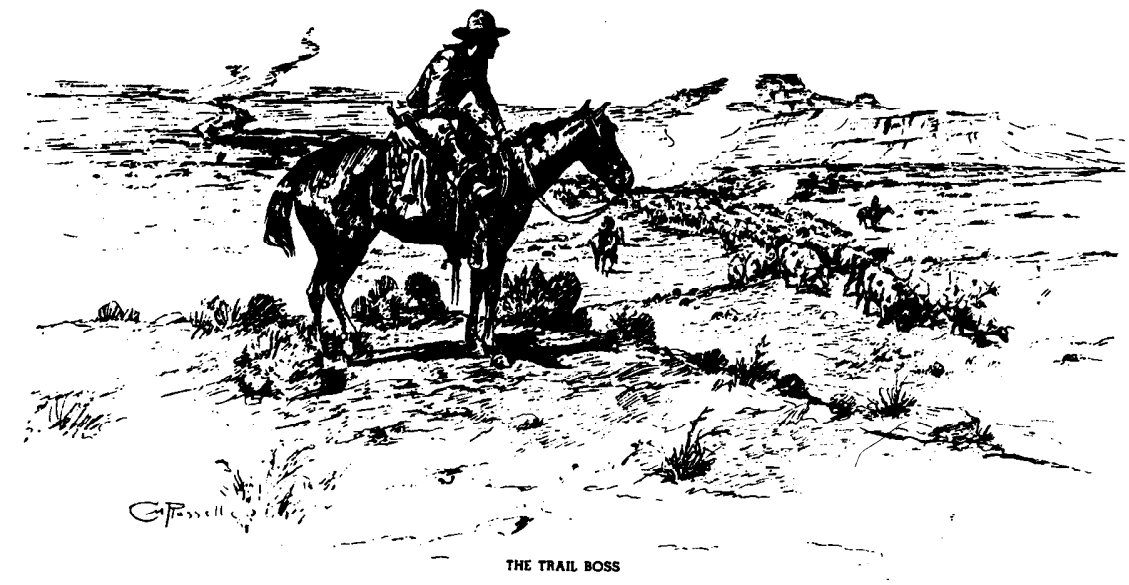

\section{Membership in the Society for Range Management. . .}

is open to those engaged in or interested in the study. management, or use of range ecosystems and the intelligent use of all range resources

includes research scientists, ranchers, governmental agency administrators and technical personnel. teachers, students, and people from the business community

provides members with two publications-one oriented to research (Journal of Range Management) and the other oriented to practical resource management (Rangelands) offers opportunities for face-to-face exchange of ideas at local, national, and intemational meetings of the Society.

Dues vary according to type of membership and geographical section. For application forms and additional information, contact the:

Executive Secretary

Society for Range Management

2760 West Fifth Avenue

Denver. Colorado 80204

(303) 571-0174 